\title{
Raskaudenkeskeyiyspyyntöönsä kielteisen vastauksen saaneista potilaista ja ko. raskauksien myöhemmistä kohtaloista
}

\section{Kalevi Niemineva ja Mikko Olki.}

Legaali raskaudenkeskeytys on kaikissa sivistysmaissa, lukuunottamatta katolisen kirkon piiriin kuuluvia, hyväksytty oikeaksi toimenpiteeksi silloin, kun tiettyjen lääketieteellisten tai lääketieteellis-sosiaalisten syiden nojalla on todennäköistä, että raskauden jatkuminen muodostaa uhkan äidin hengelle tai terveydelle.

Eri maissa on lainsäädäntöteitse pyritty tarkemmin määräämään niistä lääketieteellisistä ja sosiaalisista seikoista, jotka lääkäri on velvollinen ottamaan huomioon joutuessaan harkitsemaan raskaudenkeskeyttämistä. Suomessa astui laki raskaudenkeskeyttämiseștä voimaan 1.VII. 1950 .

Kokemus on osoittanut, ettei mikään laki, oli se sitten kuinka selvä ja vallitsevia oikeus- ja moraalikäsityksiä vastaava tahansa, voi yksinään tuoda ratkaisua rikollisista raskaudenkeskeytyksistä muodostuneeseen lääketieteellis-sosiaaliseen ongelmaan. Tämän ongelman syyt ovat sangen moninaiset, ja useimmiten taustalta on löydettävissä laadultaan puhtaasti sosiaalisia tekijöitä. Suomessa on tätä vaikeaa kysymystä valottanut Timonen useissa eri yhteyksissä. Tarvitaan määrätietoista, rakentavaa yhteiskunnallista kasvatus- ja valistustoimintaa sekä järkiperäistä syntyvyyden säännöstelyn neuvontaa »aborttimentaliteetin» poistamisekși, ennenkuin voidaan odottaa tervehtymistä tässä visaisessa kysymyksessä. Tämä kaikki merkitsee toimintaa 
laajalla rintamalla ja vaatii vuosia, kenties vuosikymmeniä, ennenkuin tulokset alkavat näkyä. Raskaudenkeskeytyslakia maahamme säädettäessä kiinnitettiin heti erikoista huomiota tähän ennakolta ehkäisevään työhön. Tällöin perustettiin ns. sosiaalineuvoloita, joiden tarkoituksena juuri on vaikuttaa positiivisesti, toisaalta henkisen tuen avulla, toisaalta opastamalla raskautensa vuoksi vaikeuksiin joutuneet äidit tarkoin tuntemaan nykyisen yhteiskunnan tarjoama monipuolinen apu. Sosiaalineuvolatoiminnan avulla on katsottu voitavan nopeasti ja suoranaisesti vaikuttaa rikollisten keskenmenojen torjumiseksi (Kaprio 1949). Näihin neuvoloihin on pyritty saamaan ohjatuksi terveydenhoitohenkilöstön avulla kaikki ne potilaat, jotka haluavat raskaudenkeskeytystä, mutta joiden pyrkimys tähän johtuu lähinnä sosiaalisista syistä (lääketieteellisessä mielessä rajatapauksia). Sosiaalineuvolalla on mahdollisuus erikoislääkäreistä kokoonpantuna elimenä tehdä a.a.p.-päätös rajatapausten kohdalla, mutta sen tärkeimpänä tavoitteena on vaikuttaa potilaaseen sillä tavoin, että hän haluaa viedä tämän raskautensa onnelliseen päätökseen. Tässä yhteydessä emme katso aiheelliseksi lähemmin puuttua sosiaalineuvolan käytännölliseen työhön, jota on monissa eri yhteyksissä lääkäreille esitetty. (Niemineva ja Timonen 1950.)

Koska sosiaalineuvolatyö on varsin nuorta ja vastaavanluonteista toimintaa ei ole muualta löydettävissä, olemme katsoneet erittäin tarpeelliseksi, huolimatta lyhyestä toimiajasta, tarkastella saatuja kokemuksia. Tällöin olemme kiinnittäneet huomiomme siihen neuvolan työn kannalta keskeiseen kysymykseen, miten suuressa määrin neuvolan potilaisto on myöhemmin synnyttänyt, sekä toisaalta siihen, mitkä sosiaaliset ja biologis-obstetriset tekijät ovat lähinnä vaikuttaneet, että potilas raskaudenkeskeytyspyrkimykselleen kielteisen päätöksen saatuaan on päätynyt tahallisesti laittomaan »aborttiin». Onhan odotettavissa, että potilaiston luonteesța johtuen juuri tahallinen keskenmeno olis: vallitsevana ei-synnyttäneiden kohdalla. 
Tämän työn yhteydessä emme halua kosketella alan ulkomaista kirjallisuutta, koska raskaudenkeskeytystä koskevat lait ovat eri maissa suuresti erilaiset ja siten sosiaalisten ja uskonnollisten tekijäin kanssa aikaansaavat, että vastaavanluonteisissa töissä tutkimustulokset eivät ole ollenkaan toisiinsa verrattavissa. Sen sijaan olemme seuraavassa puuttuneet muutamiin yksityiskohtiin, joiden uskoisimme kiinostavan maamme lausunnonantajalääkäreitä (B-lääkäreitä).

\section{A in eisto}

Aineiston perustana ovat Helsingin sosiaalineuvolassa (esimies prof. Aarno Turunen) vuosina $1949-51$ käyneistä potilaista ne, joiden raskaudenkeskeytyspyyntöön neuvolan lääkärilautakunta suhtautui kielteisesti. (On huomattava, että Suomen aborttilaki astui voimaan 1 . VII. 50). Näinä vuosina on sosiaalineuvolassa käynyt kaikkiaan 2083 uutta potilasta, joista lääkärilautakunta käsitteli kokouksissaan kaikkiaan 1396 tapausta. Myönteinen päätös annettiin 310:lle potilaalle. Kielteisen päätöksen saaneiden 1086 potilaan kohdalla suoritettiin jälkitiedustelu kesällä 1953 kirkkoherranvirastojen ja siviilirekisterin avulla tarkoituksena todeta, miten monessa tapauksessa ko. potilaat olivat synnyttäneet myöhemmin rekisteröidyn lapsen eli tällöin meidän maassamme $600 \mathrm{~g}$ painavan. Jälkitiedusteluissa saimme vastauksen 1056 potilaasta eli $97 \%$ :sta, mitä prosenttilukua on tutkimuksemme kannalta pidettävä ehdottoman riittävänä.

Jo tässä yhteydessä haluaisimme kiinnittää huomion kahteen virhelähteeseen, jotka eivät tutkimuksemme kannalta kuitenkaan käsittääksemme ole merkitykselliset. Toinen näistä on mahdollisten spontaanien keskenmenojen osuus, sillä tietenkään eivät kaikki tapaukset, joissa myöhemmin ei ole esiintynyt synnytystä, ole tahallisesti aiheutettuja. Tämä virhelähde on sen luontoinen, että tällöin toteamamme ei-synnyttäneiden luvut ovat tahallisen raskaudenkeskeytyksen maksimiarvoja. Samaan suuntaan vaikuttaa ko. toinen virhelähde, nimittäin tapaukset, joissa lapsi on 
luovutettu pois ennen kastamista eikä tällöin ole löydettävissä asianomaisen potilaan henkikirjasta.

\section{Tulokset}

Tuloksista tärkeimmän osoittaa taulukko 1, jossa on otettu huomioon myöhemmin synnyttäneet ja ei-synnyttäneet potilaat erikseen vuosittain. Tulemme myöhemmässä käsittelyssä käyttämään synnyttäneistä potilaista merkintöä s-ryhmä ja potilaista, joilla synnytystä ei todettu, merkintöä ei-ryhmä. Taulukosta on todettavissa, että s-ryhmän suuruus on 59,8 eli $60 \%$ koko jälki-

Taulukko 1.

$\begin{array}{ccccc}\text { Vuosi } & \text { S-ryhmä } & \text { Ei-ryhmä } & \begin{array}{c}\text { Koko aineisto } \\ \text { S-ryhmän osuus } \\ \text { aineistosta }\end{array} \\ 1949 & 168 & 140 & 308 & 55 \% \\ 1950 & 172 & 121 & 293 & 59, \\ 1951 & 289 & 162 & 451 & 64, \\ \text { Yhteensä } & 629 & 423 & 1052 & 60 \%\end{array}$

tutkitusta aineistosta, eli karkeasti ottaen sosiaalineuvolan potilaista kolme viidestä on neuvolan tuen avulla saatu suhtautumaan myönteisesti raskaudentilaansa. Tätä tulosta on mielestämme pidettävä sangen tyydyttävänä, ottaen huomioon sen, että kuten aineistomme kokoonpanoa käsittelevässä luvussa totesimme, jälkitutkimuksemme ei koske ollenkaan sitä ryhmää sosiaalineuvolan potilaista, joka jo sosiaalihoitajain ymmärtäväisen suhtautumisen ja tuen jälkeen katsoi aiheettomaksi raskaudenkeskeytyksen. Kuten taulukosta 1 näemme, on vuosittain tapahtunut neuvolan tuloksia arvioitaessa parantumista. Vuonna 1949 oli sryhmän suuruus $55 \%$, vuonna $195164 \%$. Mikä on sosiaalineuvolan toiminnan todellinen merkitys tulosten parantumisessa? Tätä seikkaa arvostelléssa on muistettava monta sellaista tekijää, jotka eivät ole prosenttiluvuin osoitettavissa. Vuonna 1950 voimaanastuneen raskaudenkeskeytyslain edellyttämien tukitoimenpiteiden merkitys voidaan tässä yhteydessä jättää huomioon ottamatta, koska neuvolalla on ollut mahdollisuuksia käyttää niitä vasta vuoden 1952 alusta. Neuvolan sitä aikaisemmat tukitoimenpiteet olivat 
yksinomaan vapaaehtoisten järjestöjen tarjoamia. Tärkeä seikka on tietysti: onko neuvolaan saapuva potilaisto jo sinänsä muuttunut tulosten parantumisen kannalta edulliseen suuntaan. Tällä tarkoitamme sitä, saapuuko sinne enemmän sellaisia naisia, jotka neuvolasta kuultuaan tulevat ikäänkuin koetellakseen mahdollisuuksiaan saada legaali keskeytys. Nämä tapaukset edustavat varmaankin niitä, jotka sosiaalihoitajat jo alkuvaiheessa saavat muuttamaan mielensä. Toisaalta on kuitenkin myös niin, että neuvolan toiminnan kestettyä kauemmin potilaisto ja yleisö nopeasti toteavat, minkälaisin aihein ja minkälaisin syin neuvoloissa saa raskaudentilan keskeytetyksi, ja tällöin tietenkin vain ns. rajatapaukset saapuvat neuvolaan. Myös lääkärit lähettävät sinne yhä enemmän kaikissa suhteissa vaikeita potilaita (sen kokemuksen antaa neuvola-aineiston tarkastelu), tosin myös runsaasti sellaisia, joiden kohdalla he lähinnä katsovat olevan kysymys neuvolan tarjoamista mahdollisista tukitoimenpiteistä. Myönteiseen suuntaan tapahtunut kehitys saattaa johtua myös siitä, että neuvolan työskentelymahdollisuudet, kuten koulutetun henkilökunnan määrä ja käytettävien tukitoimenpiteiden mahdollisuus, ovat lisääntyneet. Neuvolan henkilökunnan itsensä jatkuva kehittyminen tässä työssä on niinikään vaikuttanut varmasti edulliseen suuntaan. Viimeksi mainitun seikan merkitystä ei voi riittävästi arvostaa, sillä on muistettava, että kysymyksessä on toimintamuoto, josta maassamme ei ole ollut aikaisemmin kokemuksia.

Kuten johdannossa viittasimme, haluamme tässä tutkimuksessa tarkastella myös niiden mahdollisten sosiaalisten ja biologisobstetristen tekijäin osuutta, joiden kohdalla aineistomme tarjoaa mahdollisuuksia.

$$
\text { Sosiaaliset tekijät }
$$

Y m pärist ö. Alkuvuosina (1948-51) Helsingin sosiaalineuvola oli ainoa koko maassa, ja tällöin varsin huomattava osa potilaita oli maaseudulta. Tämä seikka tarjoaa mielenkiintoisen näkökohdan tarkastelulle: onko aineistossa eroa Helsingin ja maaseu- 
dun välillä? Onhan Helsinki Suomen oloissa katsottava jo suurkaupungiksi, jonka yhteiskunnallisissa olosuhteissa nimenomaan kodin kannalta on oma leimansa. Olemme jakaneet aineiston osiin Helsinki ja maaseutu. Maaseuturyhmään on otettu myös muut kaupungit. Tämä osaksi ehkä keinotekoinen jako on kuitenkin puolustettavissa, sillä Tampereen ja Turun potilaiden osuus aineistossamme on verraten vähäinen. Helsingistä peräisin olevia potilaita on aineistossa kaikkiaan 596 ja maaseudulta 456, joten ryhmät kokonsa puolesta ovat keskenään verrattavissa. Taulukko 2 osoittaa s-ryhmän suuruuden Helsingin ja maaseudun kohdalla. Pääkaupunkilaisen ja maaseutulaisen aineiston välinen ero on varsin huomattava, vuonna 1951 jopa $14 \%$ eli maaseutu $72 \%$ ja Helsinki $58 \%$. Samoin maaseudun kohdalla tulosten parantuminen on ollut selvempää kuin Helsingin. Mitkä ovat syyt tähän Helsingin ja maaseudun väliseen eroon? Syitä on haettavissa

Taulukko 2. S-ryhmän osuus vuosittain.

$\begin{array}{rccc}\text { Vuosi } & \text { Helsinki } & \text { Maaseutu } & \text { Yhteensä } \\ 1949 & 52 \% & 60 \% & 55 \% \\ 1950 & 57, & 60 \% & 59 \% \\ 1951 & 58, " & 72, & 64,\end{array}$

usealtakin taholta: pääkaupungin asujamistosta muodostaa irtonainen aines huomattavamman osan kuin pienemmissä kaupungeissa ja maaseudulla. Myös »aborttimahdollisuus» on Helsingin kokoisessa kaupungissa suurempi, puoskarin ollessa helposti löydettävissä. Näitä näkökohtia huomattavasti tärkeämpi on suurkaupungin synnyttämä »korkean elintason mentaliteetti». Tällöin pyrkii kukin perhe säilyttämään usein keinotekoisen sosiaalisen tasonsa, vaarantamatta sitä rasituksilla ja velvoituksilla, joita uuden perheenjäsenen tulo tuo mukanaan. Samoin itsekkyys ja mukavuudenhalu ovat puhtaammissa muodoissaan löydettävissä juuri suurkaupunki-»miljöön» piiristä. Maaseudulla vallitsee vielä jatkuvasti terve suhtautuminen elämään, jota suhtautumista lisäksi tukevat uskontoon pohjautuvat, elämää kunnioittavat tavat ja perinteet. On kuitenkin myös todettava, että maaseutu ja sen 
kodit pystyvät tarjoamaan lapsille edullisemman ympäristön kuin Helsinki, jonka lasten elintilaa ilmentää parhaiten käsite »puistotäti». Maaseudun myönteisempien tulosten arvostelussa on vielä muistettava, että erilaisten tukitoimenpiteiden suorittaminen potilaalle on huomattavasti vaikeampaa.

A m m a t ti. Saadaksemme käsityksen, vaikuttaako perheen taloudellinen asema millään tavoin äidin myöhempään suhtautumiseen ei-haluttuun raskauteen, olemme pyrkineet jakamaan aineiston perheenhuoltajan ammatin perusteella kolmeen ammattiryhmään. Jako on osittain mielivaltainen, mutta antaa käsityksen eri yhteiskunnallisella tasolla elävien asennoitumisesta. Ensimmäisen ryhmän muodostavat työläiset (sekatyömiehet, maatyömiehet), joilla ei ole minkäänlaista ammattikoulutusta. Toisen ryhmän muodostavat sekä ammattikoulutuksen saaneet, kuten teknikot, sorvarit että itsenäiset tilalliset ja heihin verrattavat. Kolmannen ryhmän muodostavat yliopistollisen loppututkinnon suorittaneet ja korkeakouluopiskelijat. Taulukossa 3 merkitsemme näitä ammattiryhmiä numeroin I, II ja III. Taulukko esittää eri ammattiryhmien lukumääräisen suuruuden sekä s-ryhmän

\section{Taulukko 3.}

\begin{tabular}{lcccccc} 
& \multicolumn{2}{c}{ I } & \multicolumn{2}{c}{ II } & \multicolumn{2}{c}{ III } \\
& Kaikki & S-ryhmän & Kaikki & S-ryhmän & Kaikki & S-ryhmän \\
tapaukset & osuus $\%$ & tapaukset & osuus $\%$ & tapaukset & osuus \% \\
Melsinki & 191 & 52 & 303 & 60 & 102 & 49 \\
Maaseutu & 190 & 70 & 239 & 64 & 27 & 52 \\
Yhteensä & 381 & 61 & 542 & 62 & 129 & 50
\end{tabular}

osuuden näissä ryhmissä huomioon ottaen erikseen Helsingin ja maaseudun. Ryhmä III:n osuus koko aineistosta on pieni, edustaahan se väestössäkin lukumääräisesti pienintä yhteiskuntaluokkaa. Tämä taulukko on mielestämme kytkettävissä edellisessä luvussa esiintyneisiin ilmiöihin, nimenomaan vaikeimmissa oloissa elävien kohdalla on s-ryhmän määrä Helsingissä vain 52 ja maaseudulla 70. On todennäköistä, että Helsingissä tässä ryhmässä on paljon mistään elämän arvoista välittämätöntä ainesta, kun taas toisaalta maaseudun oloissa juuri tämän ryhmän kohdalla tyytyminen so- 
siaalineuvolan päätökseen ja luvattuun apuun on helposti ajateltavissa; johan useissa tapauksissa äidin työ hänen palattuaan neuvolasta kotiinsa on siksi raskasta, ettei hän ehdi edes ajattelemaan tahallista keskeyttämistä eikä ehkä saa irti tarpeellisia varojakaan. Ammattikoulutuksen saaneiden kohdalla tulokset ovat varsin myönteiset, mikä johtuu ehkä siitä, että tässä ryhmässä perheenjäsenet ymmärtävät jo paremmin neuvolan asiallisten ohjeiden ja toimenpiteiden merkityksen. Ryhmässä III on huomattava osuus opiskelijaperheitä, joiden kohdalla taloudelliset vaikeudet ovat suuret. Tästä saanee selityksensä mainitun ryhmän muita pienempi s-ryhmän osuus.

Tässä yhteydessä on mielenkiintoista tarkastella vaikeuksiin joutuneen naisen suhtautumista silloin kun hän on pääasiallinen perheen elättäjä taikka on ansiotyössä. Edellisiä on kaikkiaan 93 ja jälkimmäisiä 151 (koko aineistossa on 1052 tapausta). Tapauksissa, joissa vaimo on pääasiallinen elättäjä, on s-ryhmän osuus ainoastaan $37 \%$, ja missä vaimo on ansiotyössä, vastaava luku on $58 \%$. Kun vertaamme näitä koko aineistomme arvoihin, toteamme, että vaimon ollessa ansiotyössä ei s-ryhmän osuudessa ole poikkeamaa koko aineistoon nähden, kun sensijaan vaimon ollessa pääasiallinen elättäjä on synnyttäneiden määrä pienempi kuin $2 / 5$ tähän ryhmään kuuluvista naisista (koko aineistossa $3 / 5$ ). Tosin tässä ryhmässä saattaa spontaanien keskenmenojen määrä äidin ansiotyön vuoksi olla suurempi kuin muissa ryhmissä. On varsin ymmärrettävää näiden yksin perhettään huoltavien naisten vaikeudet, ja on aivan ilmeistä, että tämän ryhmän kohdalla on tukitoimenpiteitä tehostettava.

Yksinäisiä äitejä on koko aineistossa 144, heistä Helsingistä peräisin olevia 67 ja maaseudulta 77 . Yksinäisiin äiteihin on neuvolassa alusta alkaen kiinnitetty aivan erityistä huomiota. Siitä huolimatta on synnyttäneiden osuus Helsingin kohdalla $39 \%$ ja maaseudun kohdalla $53 \%$ eli molemmat luvut huomattavasti pienemmät kuin koko aineistossa. Lisäksi on todettavissa päinvastainen ilmiö kuin koko aineistossa, että s-ryhmän osuus on jatkuvasti pienentymässä. Käsittääksemme Helsingin ja maa- 
seudun ero johtuu siitä, että maaseudulta tulleisiin yksinäisiin äiteihin on neuvolan henkilökunnan ollut helpompi saada ote kuin helsinkiläisiin ja heidät on siten ollut helpompi sijoittaa tukikoteihin, ja aineiston kokonaisuudessaan ollessa pieni yksinäisten äitien kohdalla saattavat tällöin jo muutamat tapaukset muuttaa huomattavasti lukuja. Lisäksi juuri yksinäisten äitien kohdalla saattaa aineistomme esityksen yhteydessä mainitsemamme pieni virhemahdollisuus vaikuttaa eniten.

Potilaiston omat motiivit. Sosiaalisten tekijäin yhteydessä on asiallista tarkastella, millä perusteilla aineistossamme potilaat ovat raskaudenkeskeyttämisensä anoneet, ovatko he panneet suurempaa painoa sosiaalisille syille kuin terveydellisille tekijöille. Tosin motiivien arvostelussa on muistettava asiaa kosketelleen Timosen näkemys: pahaksi onneksi yksilöllisen tarpeen dynaaminen teho on riippumaton siitä, onko tarvemotiivi tietoinen vai ei. Niinpä potilaan tiedonannot aborttihalunsa syistä ovat vain raakaa materiaalia, josta on mahdotonta tai ainakin hyvin vaikeaa saada todellisia alkusyitä esille. Analysoija joutuu liikkumaan pintavesillä ja näennäisyyksissä. Terveydellinen syy oli 31 \%:ssa koko aineistossa raskaudenkeskeytyspyrkimyksen takana. Helsingin ja maaseudun suhteen ei ollut sanottavia eroja. S-ryhmän osuus terveydellisten motiivien kohdalla on $62 \%$ ja sosiaalisten motiivien kohdalla $59 \%$. Tämä tulos on yllättävä, sillä terveydellisin motiivein raskaudenkeskeytystä hakevan uskoisi rauhallisesti tyytyvän erikoislääkärilautakunnan käsitykseen, ettei äidin terveydelle tästä raskaudentilasta koidu vaaraa. Toisaalta voi olla niin, että pelkin terveydellisin motiivein keskeytystä pyytäneet on neuvolan henkilökunnan taholta jätetty vähemmälle huomiolle. S-ryhmän osuus molemmissa syyryhmissä on Helsingissä ja maaseudulla samansuuntainen.

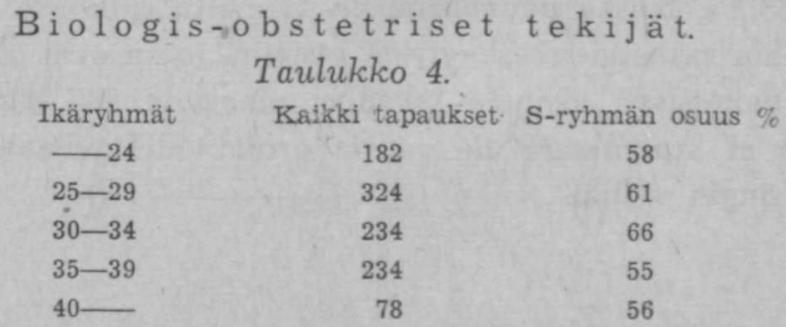


Ikä. Taulukko 4 esittää meille aineiston ikäjakautumisen. Suurin ryhmä on 25-29-vuotiaat, jolloin myös koko väestössä on syntyvyys suurin. S-ryhmän osuudessa on huomattavia vaihteluja. Sen suuruus kohoaa 30-34:ään ikävuoteen, jolloin se on $66 \%$, pieneten seuraavaan 5-vuotiskauteen mennessä $11 \%$ eli $55 \%$ :iin. Mitkä tekijät vaikuttavat s-ryhmän arvojen tämänkaltaiseen ikäjakautumiseen, ei ole helposti nähtävissä. Kuitenkin aineiston muun rakenteen tarkastelu viittaa sihen, että nuoremmissa ryhmissä naimattomien naisten voịmakas keskenmenopyrkimys ja taas toisaalta vanhemmissa ikäryhmissä suuremman lapsiluvun aiheuttamat taloudelliset vaikeudet ovat ilmiön taustana. Iän suhteen eivät Helsinki ja maaseutu eroa havaittavasti toisistaan. Edellämainittu ilmiö oli molemmissa ryhmissä todettavissa.

A violiiton kesto. Silmäillessä avioliiton keștoa ilmaisevia lukuja (taulukko 5) kiintyy huomio lähinnä siihen, että

\begin{tabular}{ccccc} 
Avioliton & \multicolumn{2}{c}{ Taulukko 5.} & \multicolumn{2}{c}{ Maaseutu } \\
kesto & Kaikki & S-ryhmän & Kaikki & S-ryhmän \\
& tapaukset & osuus \% & tapaukset & osuus \% \\
alle 2 & 31 & 74 & 16 & 75 \\
2- & 172 & 65 & 86 & 59 \\
5- yli & 326 & 53 & 287 & 68
\end{tabular}

Helsingin kohdalla on edustettuna suhteellisen paljon $(38 \%$ \% lyhyen aikaa eli 4 vuotta ja vähemmän avioliitossa olleita. Vastaava prosenttiluku maaseudun kohdalla on $27 \%$. Tämä kuvastaa mielestämme hyvin koko aineistossămme esiintyvää Helsingin ja maaseudun välistä yleistä eroa. S-ryhmän osuuteen nähden, silmälläpitäen avioliiton kestoa, on olennaisena piirteenä Helsingin ja maaseudun välillä todettava ero yli 5 vuotta kestäneissä avioliitoissa, Helsingin kohdalla $53 \%$ ja maaseudun kohdalla $68 \%$. Koska neuvolassa on tunnettu erikoista mielenkiintoa niihin raskaudenkeskeytystä etsiviin, jotka ovat olleet lyhyen aikaa naimisissa, olemme jakaneet aineiston sitä silmälläpitäen. Tällöin ei kuitenkaan ole suuria eroja todettavissa maaseudun ja Helsingin välillä. 
Taulukko 6

Aikaisemmat

Helsinki

Maaseutu

synnytykset

$\begin{array}{lcccc}\text { Kaikki } & \begin{array}{c}\text { S-ryhmän } \\ \text { tapaukset }\end{array} & \begin{array}{c}\text { Kaikki } \\ \text { osuus \% }\end{array} & \begin{array}{c}\text { S-ryhmän } \\ \text { tapaukset } \\ \text { osuus } \%\end{array} \\ - & 54 & 44 & 45 & 56 \\ 1-2 & 254 & 59 & 121 & 62 \\ 3-4 & 218 & 54 & 162 & 71 \\ 5-\text { yli } & 70 & 56 & 128 & 65\end{array}$

A i kaisemmat synnytykset. Taulukossa 6 on otettu huomioon myös yksinäiset äidit (myös lesket ja eronneet). Aikaisempia synnytyksiä on helsinkiläisillä ollut keskimäärin 2,5 ja maaseutulaisilla 3,2 . Kaksi lasta tai sitä vähemmän omaavia on Helsingin kohdalla $52 \%$, maaseudulla $36 \%$. Suuriperheisiä eli ainakin neljä lasta omaavia on edellisen kohdalla $25 \%$ ja jälkimmäisen kohdalla $43 \%$. Nämä luvut ilmaisevat selvästi, miten Helsingissä on kysymys pienemmistä perheistä, joiden jatkuvasti pieninä pitäminen liittyy jo useasti edellämainitsemaamme elintasokysymykseen. S-ryhmän pienet arvot lapsettomien kohdalla sekä Helsingissä että maaseudulla johtuvat tietysti yksinäisten äitien osuudesta, joilla jo aikaisemmin totesimme olevan voimakas taipumus tahalliseen raskaudenkeskeytykseen. Sensijaan herättää tavallaan ihmetystä, että aikaisempien synnytysten lukumäärästä huolimatta s-ryhmän osuus pysyy sekä Helsingissä että maaseudulla suhteellisen muuttumattomana.

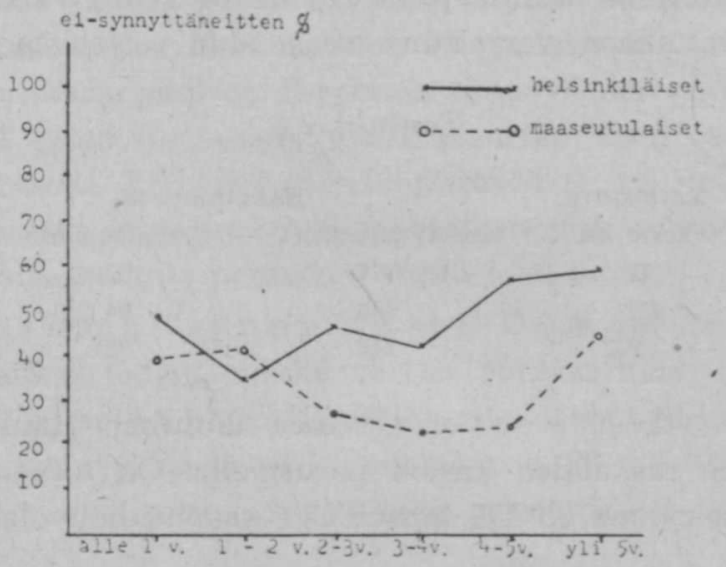


Edellisestä synnytyksestä kulunut aika. Tämän tekijän vaikutusta olemme halunneet esittää pienellä , käyrästöllä (kuva 1), joka perustuu taulukossa 7 esiintyviin arvoihin. Käyrästö ilmentää abortintaipumusta naisilla, huomioon

Taulukko 7. Edellisestä synnytyksestä kulunut aika.

\begin{tabular}{lcrcr} 
Aika & \multicolumn{2}{c}{ Helsinki } & \multicolumn{2}{c}{ Maaseutu } \\
v. & Kaikki & S-ryhmän & Kaikki & S-ryhmän \\
tapaukset & osuus $\%$ & tapaukset & osuus \% \\
alle 1 & 120 & 52 & 48 & 61 \\
$1-2$ & 186 & 66 & 136 & 59 \\
$2-3$ & 107 & 54 & 109 & 73 \\
$3-4$ & 52 & 59 & 52 & 77 \\
$4-5$ & 28 & 43 & 25 & 76 \\
yli 5 & 49 & 41 & 41 & 56
\end{tabular}

ottaen edellisestä synnytyksestä kulunut aika. Käyrästö osoittaa, miten väliajan kasvaessa yhdestä vuodesta eteenpäin aborttitaipumus asteittain lisääntyy. Lisääntyminen on havaittavissa sekä Helsingin että maaseudun kohdalla, tosin jälkimmäisessä tapauksessa ei niin voimakkaana. Tämän ilmiön katsomme johtuvan lähinnä siitä, että kuta kauemmaksi etääntyy edellinen synnytys, ts. lapsi varttuu, sitä paremmiksi käyvät äidin mahdollisuudet ryhtyä ansiotyöhön, tai muut kodin ulkopuoliset harrastukset astuvat etualalle. Erikoisen huomion ansaitsee Helsingin kohdalla pieni sryhmän arvo niillä naisilla, joilla edellisestä synnytyksestä ei ollut kulunut vuottakaan, verrattuna maaseudun vastaavaan arvoon.

\section{Taulukko 8.}

\begin{tabular}{ccc} 
Raskauden & \multicolumn{2}{c}{ Koko aineisto } \\
kesto kk. & Kaikki tapaukset & S-ryhmän osuus \\
II & 372 & $53 \%$ \\
III & 465 & 64, \\
IV & 215 & $72, "$
\end{tabular}

$\mathrm{R}$ askauden kesto. Oheinen taulukko (taul. 8) jakaa aineistomme raskauden keston perusteella. On todettava, miten huomattava ryhmä eli $1 / 5$ tapauksista saapuu neuvolaan raskau- 
dentilan ollessa jo IV raskauskuukaudessa. Tarkasteltaessa s-ryhmän osuutta raskauden keston mukaan todetaan, miten sen osuuden kasvu on lähes $10 \%$ siirryttäessä raskauden II kuukaudesta III:een ja taas IV:een kuukauteen. Tämä kulku on varsin luonnollista; kuta varhemmin potilaat saapuvat sosiaalineuvolaan, sitä enemmän heille lääkärilautakunnan kielteisen päätöksen jälkeen jää aikaa harkita muita mahdollisuuksia. Toisaalta on muistettava, että IV kuukaudessa menee ohitse raskauden aiheuttama psyykinen masennustila, joka myös osaltaan vaikuttaa naisen rauhallisempaan suhtautumiseen raskaudentilaansa nähden.

A i ka i semmat keskenmenot. Tiedot aikaisemmista »aborteista» ovat epäluotettavat ja luvut aineistossamme pienet. Kaikkiaan 279 tapauksessa on niiden lukumäärästä tietoa. Kuitenkin käy selvästi ilmi, että ne, joilla on aikaisemmin ollut kolme tai enemmän abortteja, ovat ilmeisesti paljon herkemmin turvautuneet tahalliseen keskenmenoon. Näillä potilailla on s-ryhmän osuus $32 \%$ (tosin tapauksia kaikkiaan vain 41 ). Sen sijaan niillä, joilla oli yksi tai kaksi aborttia anamneesissa, s-ryhmän osuus on koko aineiston vastaavan arvon kaltainen eli $59 \%$.

Aineistossamme on niiden potilaiden määrä, joille on aikaisemmin suoritettu laillinen raskaudenkeskeytys, 39, joista 24 eli $62 \%$ kuuluu s-ryhmään. Tämä arvo vastaa koko aineistomme vastaavaa lukua.

Puoskariuhka uksen merkitystä lienee syytä tässä kohdassa tarkastella. Kaikkiaan on 79 potilasta ilmoittanut kääntyvänsä puoskarin puoleen. S-ryhmän osuus näiden potilaiden kohdalla on $38 \%$ eli siis huomattavasti pienempi kuin vastaava arvo koko aineistossa. Erikoisen silmäänpistävää se on Helsingin kohdalla. Kolmesta uhanneesta on ainoastaan yksi synnyttänyt, kun sensijaan maaseudulta peräisin olevista joka toinen.

My öh emmät synnytykset. Oman pienen mielenkiintonsa ansaitsee todeta, minkä verran potilaat ovat synnyttäneet vielä sen jälkeen kun neuvolaan tulon aiheuttanut raskaus on päättynyt joko synnytykseen tai keskenmenoon. 93 tapauksessa eli 8,8 $\%$ :ssa koko aineistosta potilaat ovat synnyttäneet lapsen tämän 